\title{
HUBUNGAN KOMUNIKASI PERAWAT DENGAN STRES HOSPITALISASI ANAK DI RUANG PERAWATAN ANAK RSUD KOTA MAKASSAR
}

\author{
Alfiah A \\ STIKES Nani Hasanuddin Makassar \\ (Alamat Korenpondensi : alfiah@stikesnh.ac.id/081355104955)

\begin{abstract}
ABSTRAK
Hospitalisasi adalah suatu keadaan krisis pada anak, saat anak sakit dan dirawat di rumah sakit. Tujuan penelitian ini adalah untuk mengetahui hubungan komunikasi perawat dengan stres hospitalisasi pada anak di ruangan perawatan anak RSUD. Kota Makassar. Jenis penelitian ini adalah cross sectional dengan menggunakan desain uji Chi-square. Jumlah sampel dalam penelitian ini adalah sebanyak 71 responden yang didapat menggunakan teknik simple random sampling yang sesuai dengan kriteria sampel. Hasil penelitian ini menunjukkan bahwa menunjukkan bahwa dari total 71 responden, perawat yang komunikasinya kurang efektif berjumlah 56 responden $(78,9 \%)$, dimana terdapat 50 anak $(70,4 \%)$ yang mengalami stres hospitalisasi dan 6 anak $(8,5 \%)$ yang tidak mengalami stres hospitalisasi. Sedangkan perawat yang memiliki komunikasi efektif berjumlah 15 responden, dimana terdapat 7 anak $(9,9 \%)$ yang mengalami stres hospitalisasi dan 8 anak $(11,3 \%)$ yang tidak mengalami stres hospitalisasi dengan hasil uji statistik chi-square $(p=0,001)<$ nilai $\alpha(0,05)$. Kesimpulan penelitian ini ada hubungan antara komunikasi perawat dengan stres hospitalisasi pada anak di ruangan perawatan anak di RSUD Kota Makassar.
\end{abstract}

\section{Kata Kunci : Komunikasi Perawat, Stres Hospitalisasi Pada Anak}

\section{PENDAHULUAN}

Hospitalisasi dapat dianggap sebagai suatu pengalaman yang mengancam dan merupakan sebuah stressor, serta dapat menimbulkan krisis bagi anak dan keluarga. Hal ini mungkin terjadi karena anak tidak memahami mengapa di rawat, stress dengan adanya perubahan akan status kesehatan, lingkungan dan kebiasaan sehari-hari dan keterbatasan mekanisme koping (Utami Y, 2014).

Stress adalah suatu respon umum non spesifik terhadap tuntutan fisik ataupun emosional, baik dari dalam lingkungan maupun luar lingkungan. (Hidayat, 2013). Hospitalisasimerupakan suatu proses dimana karena alasan tertentu atau darurat mengharuskan anak untuk tinggal di RS, menjalani terapi perawatan sampai pemulangannya kembali ke rumah. Menurut WHO, hospitalisasi merupakan pengalaman yang mengancam ketika anak menjalani hospitalisasi karena stressor yang dihadapi dapat menimbulkan perasaan tidak aman (Utami Y, 2014).

Angka kesakitan anak di Indonesia berdasarkan Survey Kesehatan Nasional (Susenas) tahun 2010 yang dikutip oleh Apriany (2013), di daerah perkotaan menurut kelompok usia 0-4 tahun sebesar $25,8 \%$, usia 5-12 tahun sebanyak $14,91 \%$, usia $13-15$ tahun sekitar 9,1\%, usia 16-21 tahun sebesar $8,13 \%$. Angka kesakitan anak usia 0-21 tahun apabila dihitung dari kesuluruhan jumlah penduduk adalah $14,44 \%$. Anak yang dirawat di rumah sakit akan berpengaruh pada kondisi fisik dan fsikologinya, Hal ini disebut dengan hospitalisasi (Kalluas I, 2015).

Berdasarkan hasil penelitian yang dilakukan oleh Umi S (2013) dengan judul "Efektifitas Lingkungan Terapeutik Terhadap Reaksi Hospitalisasi Pada Anak" dengan hasil uji antara reaksi hospitalisasi pada kelompok intervensi dan kelompok kontrol menunjukkan bahwa angka signifikan dari variabelreaksi hospitalisasi yang meliputi kecemasan anak $(p$-value $=0,004)$, sikap kooperatif (pvalue $=0,000)$, mood anak ( $p$-value $=0,000)$, dan sikap penerimaan pada petugas ( $p$ value $=0,000$ ) adalah efektif.

Berdasarkan hasil penelitian yang dilakukan oleh Dyna A (2013) dengan judul "Hubungan antara hospitalisasi anak dengan tingkat kecemasan responden tua" berdasarkan tabel 3 didapatkan hubungan lama rawat anak dengan tingkat kecemasan responden tua menunjukkan hubungan sedang ( $r=0287)$ dan berpola positf artinya semakin lama rawat anak, maka semakin tinggi tingkat kecemasan responden tua. Nilai koefisien dengan determinasi 0,083 artinya, lama rawat anak mempengaruhu tingkat 
kecemasan responden tua sebesar 8,3\% dan sisanya $91,7 \%$ tingkat kecemasan responden tua dipengaruhi oleh variabel lain (usia responden tua, jenis kelamin responden tua, jenis pekerjaan responden tua, tingkat pendidikan responden tua, diagnosis penyakit anak, suku bangsa, jenis kelamin anak, status pernikahan responden tua, dan dukungan perawat). Hasil uji statistic didapatkan ada hubungan yang signifikan antara lama rawat anak dengan kecemasan responden tua $(p=0,007)$.

Berdasarkan data primer yang diperoleh dari bagian Rekam Medis RSUD. KotaMakassar, jumlah pasien anak rawat inap 2015 sebanyak 1868 anak, tahun 2016 sebanyak 2418 anak, tahun 2017 bulan maret sebanyak 245 anak. Dan rata-rata dari jumlahkeseluruhan pasien banyak di dapatkan kejadian stress hospitalisasi

Berdasarkan uraian tersebut, maka peneliti tertarik untuk melakukan penelitian tentang Hubungan komunikasi perawat dengan stres hospitalisasi pada anak di ruang perawatan anak RSUD Kota Makassar.

\section{BAHAN DAN METODE}

Lokasi, Populasi, dan Sampel

Penelitian ini dilaksanakan di RSUD Kota Makassar pada tanggal 24 Desember 2018 sampai 24 Januari 2019. Populasi dalam penelitian ini adalah semua anak yang dirawat di perawatan anak RSUD Kota Makassar sebanyak 245 anak, dengan sampel didapatkan 71 anak berdasarkan rumus slovin dengan teknik simple random sampling. Sampel tersebut kemudian dipilah berdasarkan karakteristik dan kriteria sampel berdasarkan:

1. Kriteria Inklusi:

a. Anak yang dirawat di ruang perawatan anak RSUD Kota Makassar

b. Ibu yang bersedia saat anaknya diobservasi pada saat penelitian berlangsung

c. Anak yang memiliki responden tua yang bisa membaca dan menulis.

d. Anak yang diizinkan oleh responden tua menjadi subjek penelitian.

2. Kriteria Eksklusi :
a. Anak yang memiliki responden tua yang tidak hadir pada saat penelitian.
b. Ibu yang tidak bersedia anaknya diobservasi.

\section{Pengumpulan Data}

1. Pengumpulan data primer diperoleh dengan menggunakan kuesioner yang telah disediakan oleh peneliti.
2. Pengumpulan data sekunder diperoleh dari RSUD Kota Makassar.

Pengolahan Data:

1. Editing

Hasil angket yang dikumpulkan melalui kuesioner perlu disunting (edit) terlebih dahulu. Kalau tenyata masih ada data atau informasi yang tidak lengkap, dan tidak mungkin dilakukan wawancara ulang, maka kuesioner tersebut dikeluarkan.

2. Coding sheet

Lembaran atau kartu kode berisi nomor responden, dan nomor pertanyaan.

3. Data entry

Mengisi kolom lembar sesuai dengan jawaban masing-masing pertanyaan.

4. Tabulasi

Membuat tabel data, sesuai dengan tujuan penelitian atau yang diinginkan oleh peneliti (Notoatmodjo, Metodologi Penelitian Kesehatan, 2014)

Analisa Data

1 Analisis univariat

Analisa univariat pada umumnya dalam analisis ini menghasilkan distribusi frekuensi dan persentase dari tiap variabel (Notoatmodjo, 2014).

2 Analisis bivariate

Analisis bivariat yang dilakukan terhadap dua variabel yang diduga berhubungan atau berkorelasi (Notoatmodjo, 2014).

\section{HASIL PENELITIAN}

1. Analisis Univariat

Tabel 1. Analisis Distribusi Karakteristik Responden di RSUD Kota Makassar $(n=71)$

\begin{tabular}{|c|c|c|}
\hline $\begin{array}{c}\text { Karakteristik } \\
\text { responden }\end{array}$ & $\mathrm{n}$ & $\%$ \\
\hline Umur & 30 & 42,3 \\
$26-35$ tahun & 41 & 57,7 \\
36-45 tahun & 28 & 39,4 \\
Umur $6-8$ tahun & 30 & 42,3 \\
9-10 tahun & 13 & 18,3 \\
$11-12$ tahun & & \\
\hline
\end{tabular}

Berdasarkan tabel 1 menunjukkan bahwa dari 71 responden, anak yang berjenis kelamin laki-laki sebanyak 30 responden $(42,3 \%)$, dan anak yang berjenis kelamin perempuan sebanyak 41 responden $(75,7 \%)$. Sedangkan pada variabel umur, menunjukkan bahwa dari 71 responden, anak yang berumur 6-8 tahun sebanyak 28 responden $(39,4 \%)$, anak yang berumur $9-10$ tahun sebanyak 30 
responden $(42,3 \%)$, dan anak yang berumur 11-12 tahun sebanyak 13 responden $(18,3)$.

2. Analisis bivariat

Tabel 2. Analisis Hubungan Komunikasi Perawat dengan stres hospitalisasi pada anak di ruang perawatan anak RSUD Kota Makassar $(n=71)$

\begin{tabular}{|c|c|c|c|c|c|c|}
\hline \multirow{3}{*}{$\begin{array}{c}\text { Komunikas } \\
\text { i Perawat }\end{array}$} & \multicolumn{4}{|c|}{$\begin{array}{c}\text { Stress hospitalisasi } \\
\text { pada anak }\end{array}$} & \multirow{2}{*}{\multicolumn{2}{|c|}{ Total }} \\
\hline & \multicolumn{2}{|c|}{ mengalami } & \multicolumn{2}{|c|}{$\begin{array}{c}\text { Tdk } \\
\text { mengalami }\end{array}$} & & \\
\hline & $n$ & $\%$ & $\mathrm{n}$ & $\%$ & $\mathrm{n}$ & $\%$ \\
\hline $\begin{array}{l}\text { Kurang } \\
\text { efektif }\end{array}$ & 50 & 70,4 & 6 & 8,5 & 56 & 100 \\
\hline efektif & 7 & 9,9 & 8 & 11,3 & 15 & 100 \\
\hline Total & 57 & 80,3 & 14 & 19,7 & 71 & 100 \\
\hline & & $p=0,0$ & & & & \\
\hline
\end{tabular}

Berdasarkan Tabel 2 menunjukkan bahwa dari total 71 responden, perawat yang komunikasinya kurang efektif berjumlah 56 responden $(78,9 \%)$, dimana terdapat 50 anak $(70,4 \%)$ yang mengalami stres hospitalisasi dan 6 anak $(8,5 \%)$ yang tidak mengalami stres hospitalisasi. Sedangkan perawat yang memiliki komunikasi efektif berjumlah 15 responden, dimana terdapat 7 anak $(9,9 \%)$ yang mengalami stres hospitalisasi dan 8 anak $(11,3 \%)$ yang tidak mengalami stres hospitalisasi.

Berdasarkan hasil uji statistik dengan Chi-square diperoleh nilai $p=0,001$. Karena nilai $p<\alpha=0,05$, maka hipotesis nol ditolak dan hipotesis alternatif diterima. Interpretasi ada hubungan komunikasi perawat dengan stres hospitalisasi anak di ruang perawatan anak RSUD Kota Makassar..

\section{PEMBAHASAN}

Berdasarkan hasil penelitian yang telah dilakukan di RSUD Kota Makassar dari total 71 responden, perawat yang komunikasinya kurang efektif berjumlah 56 responden $(78,9 \%)$, dimana 50 anak $(70,4 \%)$ yang mengalami stres hospitalisasi dan terdapat 6 anak $(8,5 \%)$ yang tidak mengalami stres hospitalisasi. Hal tersebut disebabkan karena anak tersebut pernah dirawat sebelumnya lebih mudah beradaptasi dengan lingkungan di rumah sakit. Apabila pengalaman sebelumnya menyenangkan maka anak akan memiliki rasa takut yang lebih rendah sehingga lebih kooperatif selama dirawat. Dalam penelitian ini terdapat pula 7 responden yang tidak pernah dirawat sebelumnya mengalami stres. Itu disebabkan oleh faktor lingkungan. Anak selama di rumah sakit akan terpapar dengan situasi baru yang menibulkan rasa tidak aman pada anak. Di rumah sakit, anak akan menemukan berbagai peralatan kesehatan yang tidak ditemui selama dirumah, situasi ruangan yang berbada dengan ruangan lain di rumah, anak akan bertemu dengan pasien lain, serta petugas kesehatan dari berbagai profesi yang belum dikenalnya secara baik oleh anak. Hal tersebut dipengaruhi oleh subvariabel lain yaitu lingkungan rumah sakit. Sehingga tidak dapat memberikan jaminan bahwa komunikasi perawat merupakan satusatunya faktor yang dapat mempengruhi terjadinya stres hospitalisasi pada anak

Hal Ini sejalan dengan penelitian yang dilakukan oleh Margareta Molo Nae (2015) yang berjudul "Faktor-faktor yang mempengaruhi kecemasan anak sekolah yang di rawat di ruang perawatan anak rumah sakit umum daerah kota makassar" menyatakan bahwa ada hubungan yang signifikan antara komunikasi terapeutik dengan stres hospitalisasi pada anak yang di rawat di ruangan perawatan anak yang dibuktikan dengan nilai kemaknaan $p=0,004$.

Sesuai teori yang diungkapkan oleh Cusway \& Lodge, yang dikutip oleh Santa Manurung (2011) dalam bukunya yang berjudul "Keperawatan Profesional" mengatakan bahwa komunikasi juga merupakan pertukaran atau keterangan dalam rangka menciptakan rasa saling mengerti serta rasa saling percaya demi terwujudnya hubungan yang baik antara seseresponden dengan responden lain.

\section{KESIMPULAN}

Penelitian ini ada hubungan antara komunikasi perawat dengan stres hospitalisasi pada anak di ruangan perawatan anak di RSUD Kota Makassar.

\section{SARAN}

Diharapkan tenaga kesehatan khususnya perawat agar dapat meningkatkan pengethuan serta pemahaman terkait dengan teknik komunikasi yang efektif dalam berkomunikasi pada anak untuk mengurangi stres hospitalisasi pada anak.

\section{DAFTAR PUSTAKA}

Ambarwati, Fitri.R, dan Nita Nasution. (2012). Buku Pintar Asuhan Keperawatan Bayi \& Anak. Yogyakarta: Cakrawala IImu 
Hidayat A A A. (2014). Riset Keperawatan dan Teknik Penulisan IImiah. Jakarta: Salemba Medika.

Kaluas, I. (2015). Perbedaan Terapi Bermain Puzzle dan Bercerita Terhadap Kecemasan Anak Usia Prasekolah (3-5 tahun) Selama Hospitalisasi di Ruang Anak RS TK. III. R. W.Mongisidi Manado. eJournal Keperawatan (e-Kp). http://ejournal.unsrat.ac.id/index.php/jkp/article/ download/7969/7527.

Lestari, T. (2015). Kumpulan Teori untuk Kajian Pustaka Penelitian Kesehatan. Yogyakarta: Nuha Medika.

Manurung, S. (2011). Keperawatan Profesional. Jakarta: Trans Info Media.

Nae, M,M. (2015). Faktor-Faktor yang Mempengaruhi Kecemasan Anak yang di Rawat di RSUD Kota Makassar.

Nursalam. (2016). Metodologi Penelitian IImu Keperawatan. Jakarta: Salemba Medika.

Pieter, Herri Zan. dkk, (2011). Pengantar Psikologi Untuk Keperawatan. Jakarta: Prenada Media Group.

Priyoto, 2014. Konsep Manajemen Stress. Yogyakarta: Nuha Medika.

Saam, Z \& Wahyuni, S. (2013). Psikologi Keperawatan. Jakarta: Raja Grafindo Persada.

Soekidjo N. (2012). Metodologi Penelitian Kesehatan. Jakarta: Rineka Cipta.

Utami Y. (2014). Dampak Hospitalisasi Terhadap Anak. Jurnal Ilmiah WIDYA. http://www.ejournal.jurwidyakop3.com/index.php/jurnal-ilmiah/article /viewfile/177/156.

Ulfa M. (2015). Beragam Gangguan Paling Sering Menyerang Anak. Yogyakarta: FlashBooks.

Wiku, Adisasmito. (2012). Audit Lingkungan Rumah Sakit. Jakarta: Raja Grafindo Persada 